\title{
ASIP Gene
}

National Cancer Institute

\section{Source}

National Cancer Institute. ASIP Gene. NCI Thesaurus. Code C131341.

This gene is involved in the modulation of melanogenesis. 